ISSN 2236-0859

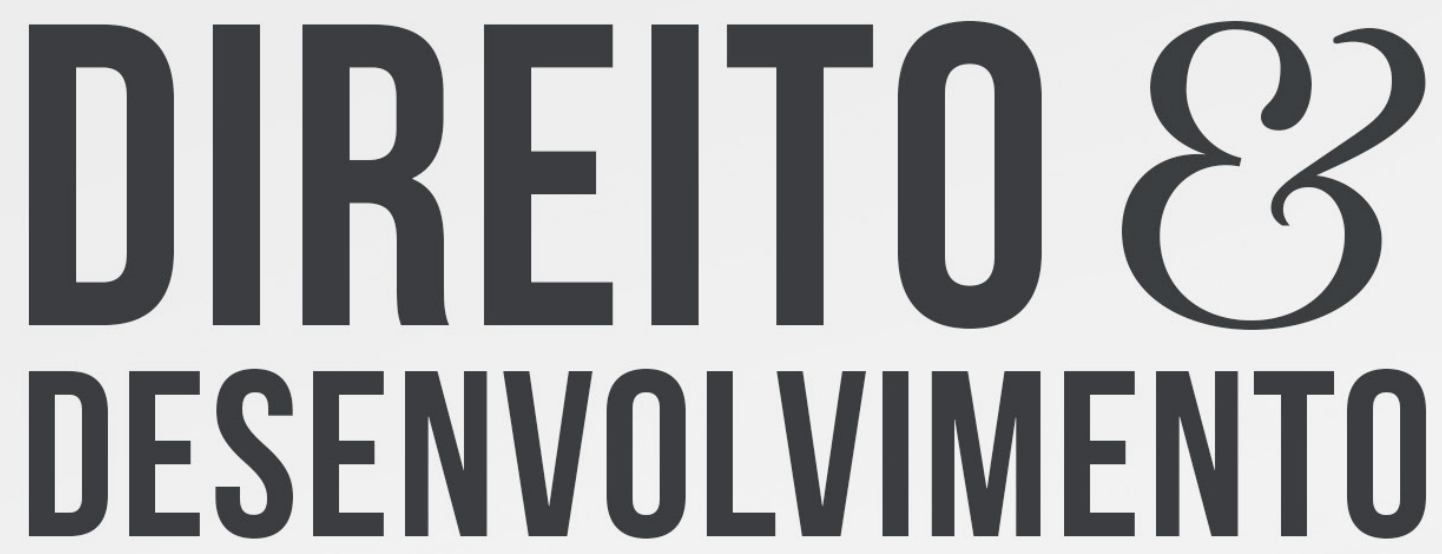

REVISTA DO PROGRAMA DE PÓS-GRADUAÇÃO EM DIREITO MESTRADO EM DIREITO E DESENVOLVIMENTO SUSTENTÁVEL

O TAC COMO INSTRUMENTODE REGULARIZAÇÃO FUNDIÁRIA SUSTENTÁVEL: APLICACSÃO DA REURB SOCIAL NAS APPS DO LAGO DO JUÁ E RIO TAPAJÓS EM SANTARÉM-PA

MARCELOMESSIAS LEITE MAGNO FEDERICCI GOMES 


\title{
O TAC COMO INSTRUMENTO DE REGULARIZAÇÃO FUNDIÁRIA SUSTENTÁVEL: APLICAÇÃO DA REURB SOCIAL NAS APPS DO LAGO DO JUÁ E RIO TAPAJÓS EM SANTARÉM-PA
}

\author{
TAC AS INSTRUMENT OF SUSTAINABLE ENVIRONMENTAL \\ REGULARIZATION: APPLICATION OF THE SOCIAL REURB IN \\ THE APPS OF LAKE JUÁ AND RIO TAPAJÓS IN SANTARÉM-PA
}

Recebido: 05/07/2019

Marcelo Messias Leite ${ }^{1}$

Aprovado: 15/12/2019

\author{
Magno Federicci Gomes ${ }^{2}$
}

\section{RESUMO:}

O objetivo deste artigo éanalisar a Lei de Regularização Fundiária Urbana, no 13.465/2017, diploma legal sobre ocupações antrópicas em Áreas de Preservação Permanente (APPs), regulamentada pelo Decreto no 9.310/2018, visando os direitos no art. 6o e 225 da Constituição da República de 1988 (CR/88). Apresentar a hipótese de regularização fundiária nas APPs do Juá e Tapajós, mediante o Termo de Ajustamento de Conduta (TAC). Será utilizada metodologia de pesquisa documental/bibliográfica, com raciocínio logico/dedutivo. Os resultados apontam que é possível efetivar o direito a moradia pelo TAC, desde que aplicado por instrumentos técnicocientíficos que garantam a proteção ambiental em APPs.

Palavras-chave: Área de Preservação Permanente. Termo de Ajustamento de Conduta. Regularização Fundiária Urbana Social.

\begin{abstract}
:
The objective of this article is to analyze the Urban Land Regularization Law, no 13.465 / 2017, legal diploma on anthropic occupations in Areas of Permanent Preservation (APPs), regulated by Decree 9.310 / 2018, aiming at the rights in art. 6 and 225 of the 1988 Constitution (CR / 88). To present the hypothesis of land regularization in the APPs of the Juá and Tapajós, through the Term of Adjustment of Conduct (TAC). Documentary / bibliographic research methodology will be used, with logical / deductive reasoning. The results indicate that it is possible to implement the right to housing by the TAC, provided that it is applied by technical-scientific instruments that guarantee environmental protection in APPs.
\end{abstract}

Keywords: Permanent Preservation Area. Term of Adjustement of Conduct. Urban Social Land Regularization.

\footnotetext{
1 Mestre em Direito Ambiental, pela Escola Superior Dom Hélder Câmara, Bolsista e Pesquisador pela FAPEMIG. Email: messiasmarceloleite@hotmail.com

2 Doutor em Direito e Mestre em Direito Processual, pela Universidad de Deusto-Espanha (Bolsa da Cátedra UNESCO e do Gobierno Vasco-Espanha). Mestre em Educação pela PUC Minas. Professor do Doutorado e Mestrado Acadêmico em Direito Ambiental e Desenvolvimento Sustentável na Escola Superior Dom Helder Câmara. Professor Adjunto da PUC Minas e Professor Titular licenciado da Faculdade de Direito Arnaldo Janssen. Advogado Email: federici@pucminas.br
} 


\section{INTRODUÇÃO}

O presente artigo abordará o Termo de Ajustamento de Conduta (TAC) como instrumento sustentável para aplicação da Regularização Fundiária Social Urbana (Reurb-S), nas Áreas de Preservação Permanente (APPs), do Lago do Juá e Rio Tapajós, em Santarém, Pará, visando responder à seguinte problemática: É possível conciliar o direito à moradia e a proteção ambiental, nas APPs, de maneira sustentável, buscando evitar o trauma social, da remoção forçada de mais de 4.493 famílias, pela tutela de urgência por força policial?

O objetivo geral é a análise da Lei no 13.465, de 11 de julho de 2017, diploma legal sobre a temática, regulamentada pelo Decreto no 9.310, de 15 de março de 2018, tendo em vista os direitos elencados nos arts. 6o e 225 da $\mathrm{CR} / 88$, respectivamente, do direito universal à moradia, em consonância com o direito ao meio ambiente ecologicamente equilibrado a todos, garantidor da sadia qualidade de vida.

O objetivo específico do presente estudo será a análise da Ação Civil Pública (ACP), no Processo no oo03993-38.2017.8.140051, com Tutela Provisória em Caráter Antecedente, e a Ação de Reintegração de Posse, no processo sob o no oo13104-51.2014.8.14.00-51.

.A pertinência temática se justifica porque nas tutelas de urgência que envolvem remoções forçadas e reintegrações de posse, em ocupações irregulares, em litígios coletivos, visando dar celeridade à proteção ambiental, não há oferecimento de audiências públicas, antes da posse de ano e dia.

Ademais, quando preveem audiências, na maioria das vezes, não é observado o que prescreve o art. 565 do Código de Processo Civil de 2015 (CPC/15), ou há insuficiência e incompatibilidade fática com seus termos, pois não há espaço para participação da comunidade local, de forma efetiva, nem a possibilidade e iniciativa cooperativa de se adequarem às exigências ambientais, com fins a captar o seu ponto de vista e percepção sobre a realidade.

As audiências públicas visam construir soluções democráticas, formar entendimento para leis específicas e atuais, que respeitem a dignidade da pessoa humana, alinhadas às necessidades do dinamismo socioambiental, pelo respectivo enfrentamento do déficit de mais de 35 (trinta e cinco) mil habitações em Santarém.

Tal déficit se dá pela expansão urbana e explosão demográfica no presente caso, em Santarém, nas áreas ambientalmente protegidas, como apresentado na reunião da Câmara Municipal de vereadores em 24/o1/2018, pela Coordenadoria Municipal de Habitação e Desenvolvimento Urbano (CHDU).

Ademais, há previsão sobre a Reurb-S, mesmo dentro de APPs, por lei geral (Lei Federal $n^{\circ} 12.651 / 2012$ ), em seu artigo 64 e seus incisos, bem como em lei específica (Lei $\mathrm{n}^{0}$ 13.465/2017), regulamentada pelo Decreto no 9.310/2018, também na Lei Municipal no 18.051/o6, que estabelece o Plano Diretor de Santarém, em seus artigos 119 e 120 e seus incisos, mesmo que haja ocupações irregulares consolidadas ou não, parcial ou totalmente, dentro de APPs urbanas, não mais se exigindo a 'comprovação de inexistência de alternativa locacional' ou 'consolidação da ocupação'.

Portanto, para a consecução dos resultados, far-se-á necessária abordagem teóricojurídica, assentada em método hipotético-dedutivo, com técnicas de pesquisa documental/ bibliográfica. O referencial teórico da pesquisa são as obras de Freitas (2016) e de Gomes e Ferreira (2017), para estabelecer o equilíbrio das dimensões da sustentabilidade.

O trabalho, no primeiro capítulo, apresentou breve histórico na formação do conceito das APPs, sua evolução legal e proteção e os diplomas legais e atuais sobre o Direito à Moradia mesmo que em espaços protegidos. 
No segundo tópico apresentou-se o estudo de caso das APPs no Lago do Juá e Rio Tapajós, em Santarém, PA, corroborados de estatísticas, com dados oficiais sobre a realidade local, de sua judicialização, bem como mapas para melhor visualização.

No terceiro tópico empenhou-se em analisar a amplitude do direito à moradia em consonância com as dimensões do desenvolvimento sustentável e as legislações pertinentes, aplicadas ao caso concreto, com intuito de alcançar ambas as suas facetas.

Buscou-se trazer, no quarto tópico, diante da problemática, a hipótese de regularização fundiária nas APPs do Juá e Tapajós, mediante a Reurb-S, na possibilidade de aplicação do TAC, previsto na Lei de Ação Civil Pública (LACP) - Lei no 7.347/85, em seu art. $5^{\circ}$, § $6^{\circ}$, para implementar medidas que assegurem o uso e preservação (e ou conservação) dos recursos naturais, pelos interesses individuais, coletivos e difusos na solução de conflitos socioambientais.

\section{BREVE HISTÓRICO NA FORMAÇÃO DO CONCEITO DE ÁREA DE PRESERVAÇÃO PERMANENTE, A EVOLUÇÃO DE SUA PROTEÇÃO, DIPLOMAS LEGAIS E ATUAIS}

Para aprofundar na temática, se faz necessário resgatar pontos importantes sobre a formação do conceito de APPs, a ampliação, especificação e delimitação sobre o entorno de sua proteção, atualizando o debate com as ferramentas legais sobre regularização urbana em áreas especialmente protegidas.

Como expõe Crivellari (2016, p. 39), a origem do conceito das APPs no Brasil se deu com a ocupação do solo ao longo da expansão urbana, desenvolvimento industrial e agropecuário, surgindo a necessidade de proteger os cursos de água existentes. No antigo Código Florestal de 1934 (Decreto Federal no 23.793/34), o termo utilizado para as APPs era o conceito de "florestas protetoras", em seus artigos $3^{\circ}, 4^{\circ}$ e 22 , pois tratavam sobre a proteção da vegetação às margens de águas, para proporcionar abrigo e conservar a biodiversidade de espécimes, dando contorno ao conceito legal das APPs.

A construção da proteção do Meio Ambiente se deu de forma paulatina, em trajetória retilínea, em cada decisão legislativa, pela percepção socioambiental, de maneira que foi incorporada ao direito, a proteção para as novas formas de interação e resultados de análises científicas sobre as atuações humanas e suas consequências, em seu meio socioambiental, especialmente no ambiente urbano e atividades econômicas industriais com grandes impactos.

De fato, com a expansão urbana e o desenvolvimento, no Pós-Revolução industrial, foram necessários planejamento e regulamentação para qualquer atividade humana que causasse significativo impacto ambiental, assim elaborou-se, ao longo das décadas de 20 e 30 , o antigo Código Florestal (Lei 4.771/65), ora revogado pelo atual Código Florestal, que no artigo $\mathbf{1}^{\circ}$, $§ 2^{-}$, II instituiu as APPs, definindo o seu conceito, finalidade e essência, para a proteção do meio ambiente, mas sempre com a finalidade de proporcionar o bem estar das populações humanas, com a seguinte temática:

[...] área de preservação permanente: área protegida nos termos dos arts. $2^{\circ}$ e $3^{\circ}$, desta Lei, coberta ou não por vegetação nativa, com a função ambiental de preservar os recursos hídricos, a paisagem, a estabilidade geológica, a biodiversidade, o fluxo gênico de fauna e flora, proteger o solo e assegurar o bem-estar das populações humanas. grifo nosso (BRASIL, 1965).

A amplitude e abrangência na proteção das APPs vão além da proteção de árvores ou florestas, ou recursos hídricos, encostas íngremes, áreas topograficamente sensíveis e diferenciadas e ambientes costeiros, mas a finalidade da preservação geral de todo o ecossistema 
tem também um caráter utilitário, visando proporcionar o bem estar para as presentes e futuras gerações.

Com a Constituição da República de 1988 (CR/88), em seu art. 225, § 1º, III, incorporouse o dever do Poder Público de definir, em todas as unidades da Federação, espaços territoriais e seus componentes a serem especialmente protegidos, sendo a alteração e a supressão permitidas somente através de lei, vedada qualquer utilização que comprometesse a integridade dos atributos que justifiquem sua proteção. Nesse sentido, o direito francês elucida a questão pelo conceito de espaces naturels sensibles, definidos pelo Ministério da Ecologia e do Desenvolvimento Sustentável da França como:

\footnotetext{
áreas protegidas devem ser constituídos de áreas cuja característica natural é ameaçada e tornada vulnerável, atualmente ou potencialmente, devido à pressão urbana ou ao desenvolvimento de atividades econômicas e recreativas, ou por causa de particular interesse, tendo em conta a qualidade do sítio ou as características das espécies animais ou vegetais [...] (COLLECTIF, 2010, p 10. $)^{3}$.
}

Assim, em análise holística, devem ser considerados os aspectos sociais inerentes à propriedade, dispostos na inteligência do art. 6º , da livre iniciativa, do trabalho, da estrutura social, objetivando o pleno desenvolvimento dos seres humanos, pela efetivação dos direitos fundamentais, dispostos na mesma CR/88 (BRASIL, 1988).

A CR/88 tem como finalidade apontar a direção para elaboração de leis gerais e abstratas, de antemão, visando abranger o máximo de situações possíveis sem comprometer a regulamentação da transformação e dinâmica socioambiental.

Assim, os casos concretos deverão ser tratados por leis específicas, resoluções e portarias, ou pelo Poder Judiciário, na análise do caso concreto, com participação da comunidade local, por audiências púbicas e consultas prévias, que alcancem as peculiaridades e minúcias, às vezes somente percebidas pela comunidade local, pela sua dor e sofrimento, na labuta do dia a dia, para a construção de políticas publicas e decisões mais acertadas, já que a comunidade local será a destinatária da norma, de modo que haja pluralismo comunitário-participativo, pela ação da comunidade local na formação do direito, como apresentado por Santos (2011):

[...] Enquanto os estudos clássicos sobre o pluralismo jurídico puderam desfrutar de alguma facilidade analítica e de investigação, optando por uma estrutura conceptual que isolasse as ordens jurídicas do colonizador e do colonizado, os novos estudos sobre o pluralismo jurídico debruçam-se sobre uma teia de legalidades entrelaçadas (SANTOS, 2011, p. 115).

Com esse intuito surgiram exceções legais, como na Resolução do Conselho Nacional do Meio Ambiente (CONAMA) no 369/o6, ora revogada pelo atual código, que previa os casos excepcionais de utilidade pública, interesse social ou baixo impacto ambiental, que possibilitavam a intervenção ou supressão de vegetação em APPs, tratada também pela Medida Provisória (MP) no 759/2016, convertida na atual Lei no 13.465/2017.

Assim, a dinâmica das leis se encontravam nas várias dimensões da sociedade, introjetadas no ordenamento jurídico pela percepção imediata e futura das necessidades socioambientais.

Nesse sentido, a Lei no 11.977/o9 dispôs sobre o Programa Minha Casa, Minha Vida (PMCMV), que prevê a regularização fundiária de assentamentos localizados em áreas urbanas, abordando assuntos reflexos às matérias atinentes sobre APPs, tratadas em lei específica da 3 Tradução livre de "les espaces ayant vocation à être protégés "doivent être constitués par des zones dont le caractère naturel est menacé et rendu vulnérable, actuellement ou potentiellement, soit en raison de la pression urbaine ou du développement des activités économiques et de loisirs, soit en raison d'un intérêt particulier, eu égard à la qualité du site, ou aux caractéristiques des espèces animales ou végétales qui s'y trouvent" 
Reurb S-E. Posteriormente, a Lei Federal no 12.651/2012 (Código Florestal), em seu artigo 64, no caput, trouxe a possibilidade de regularização das ocupações antrópicas em APPs urbanas.

Toda essa dinâmica de normas se converge em um ponto comum, a saber: conciliar a permanência dos moradores da comunidade local no meio socioambiental, de forma digna e sustentável, em bem estar e paz social, com participação cidadã, no Estado Democrático de Direito, símbolo do governo popular, desde a elaboração da $\mathrm{CR} / 88$ à elaboração de leis gerais e específicas sobre a temática, considerando a interação com as comunidades locais, absorvendo os seus anseios, para apontar e examinar a possibilidade de eliminação, de correção ou de administração de riscos na parcela socioambiental afetada e, assim, a atualização do ordenamento Jurídico.

\section{O CASO ESPECÍFICO EM ANÁLISE: DÉFICIT URBANO EM SANTARÉM, DINÂMICA DA OCUPAÇÃO E A AÇÃO JUDICIAL}

Segundo dados estatísticos da Fundação João Pinheiro (FJP), em 2015, como demostrado por Souza e Viana (2018), o déficit habitacional estimado no Brasil era de 6,355 milhões de domicílios, dos quais 5,572 milhões, ou 87,7\%, estão localizados nas áreas urbanas. O Pará, com déficit de $\mathbf{2 1 7 . 1 2 8}$ moradias, se encontra em segundo lugar, em relação às Unidades da Federação, com maior déficit habitacional relativo do país, com 15,3\% (SOUZA; VIANA, 2018, p. 33).

Em Santarém, no ano de 2018, a população chegou a aproximadamente 302.667 pessoas, segundo dados estatísticos do Instituto Brasileiro de Geografia e Estatística (IBGE) 2019 e o déficit de habitação chegou a mais de 35 (trinta e cinco) mil habitações, no mesmo ano, segundo dados apresentados por Lopes, da Coordenadoria Municipal de Habitação e Desenvolvimento Urbano (CHDU), em reunião na Câmara dos Vereadores, problema esse gerado pela expansão urbana em Santarém, ocorrida às margens do Rio Tapajós, nas APPs do caso em discussão, e naquelas onde se encontra o centro, desde a fundação da cidade (PARÁ, 2018, p. 3).

Sem ter opção de moradia, por programas oficiais do governo, em Agosto de 2014, famílias de baixa renda incorreram, na primeira fase de ocupação, do Bairro Vista Alegre do Juá (até à Quadra 11) e do Bairro Salvação do Juá, (a partir da Quadra 12), objetos da Ação de Reintegração de Posse, no processo sob o no o013104-51.2014.8.14.0051, contra os ocupantes, com liminar concedida (BRASIL, 2014). Segue abaixo as imagens da densidade demográfica no presente caso, a seguir: 
Figura 1 - Densidade demográfica - Foto satélite; dinâmica da ocupação 2014

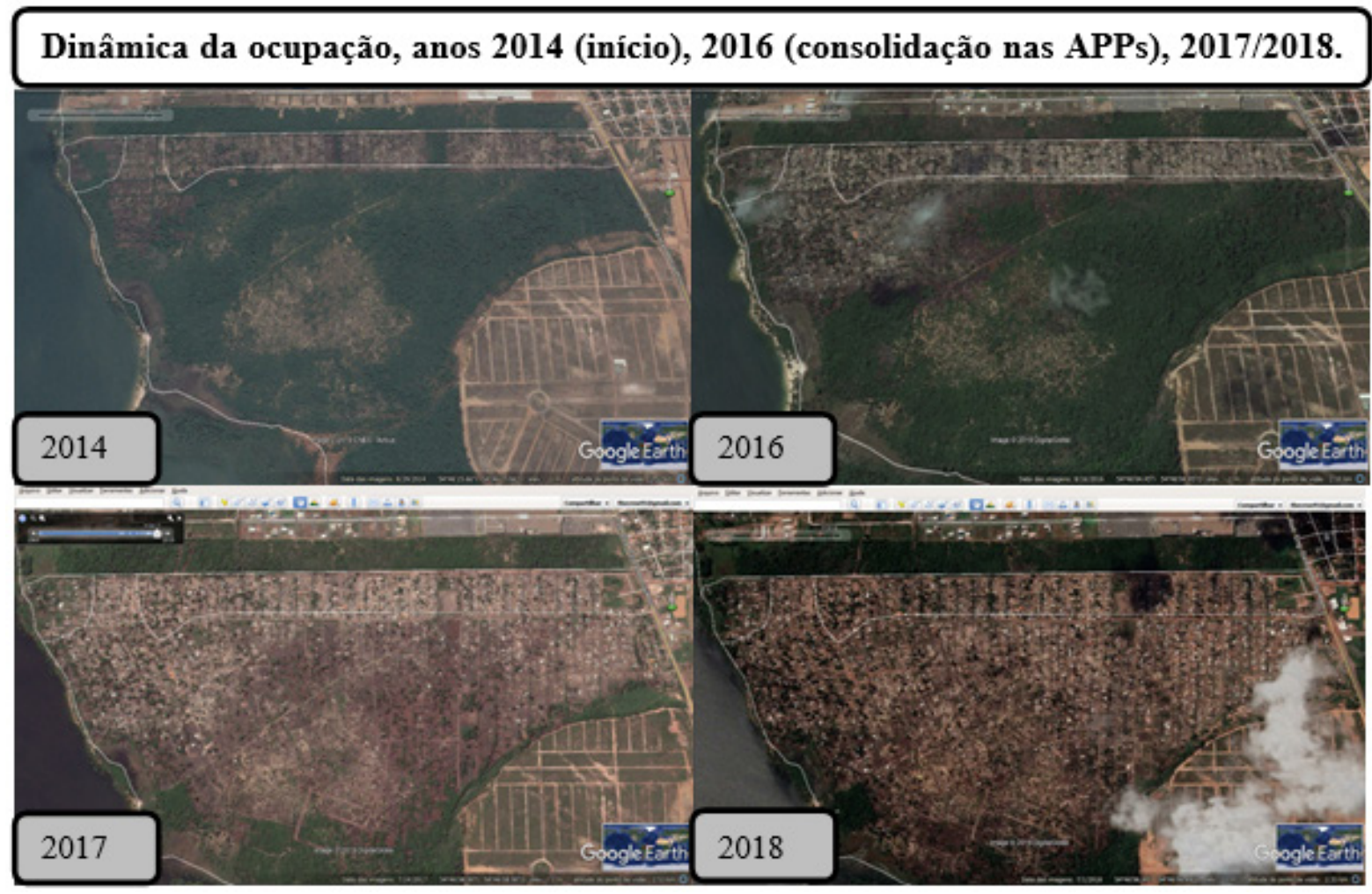

Fonte: Google Earth /2019 (Adaptação do autor)

Pelos mapas, se compreende a gravidade e seriedade do presente caso, pois a remoção forçada, com violência, retirando mais de 20 mil pessoas das ocupações irregulares dos bairros 'Vista Alegre do Juá e Bairro Salvação do Juá', respectivamente, sem local apropriado, não levando em consideração a vulnerabilidade de grupos, como: crianças e idosos, mulheres grávidas e, em geral, pessoas de baixa renda, seria violação generalizada dos direitos humanos. Segue no mapa abaixo a área já consolidada, no ano de 2018:

Figura 2 - Ocupação irregular em 2017 - Fotos satélite; situação da área (2018)

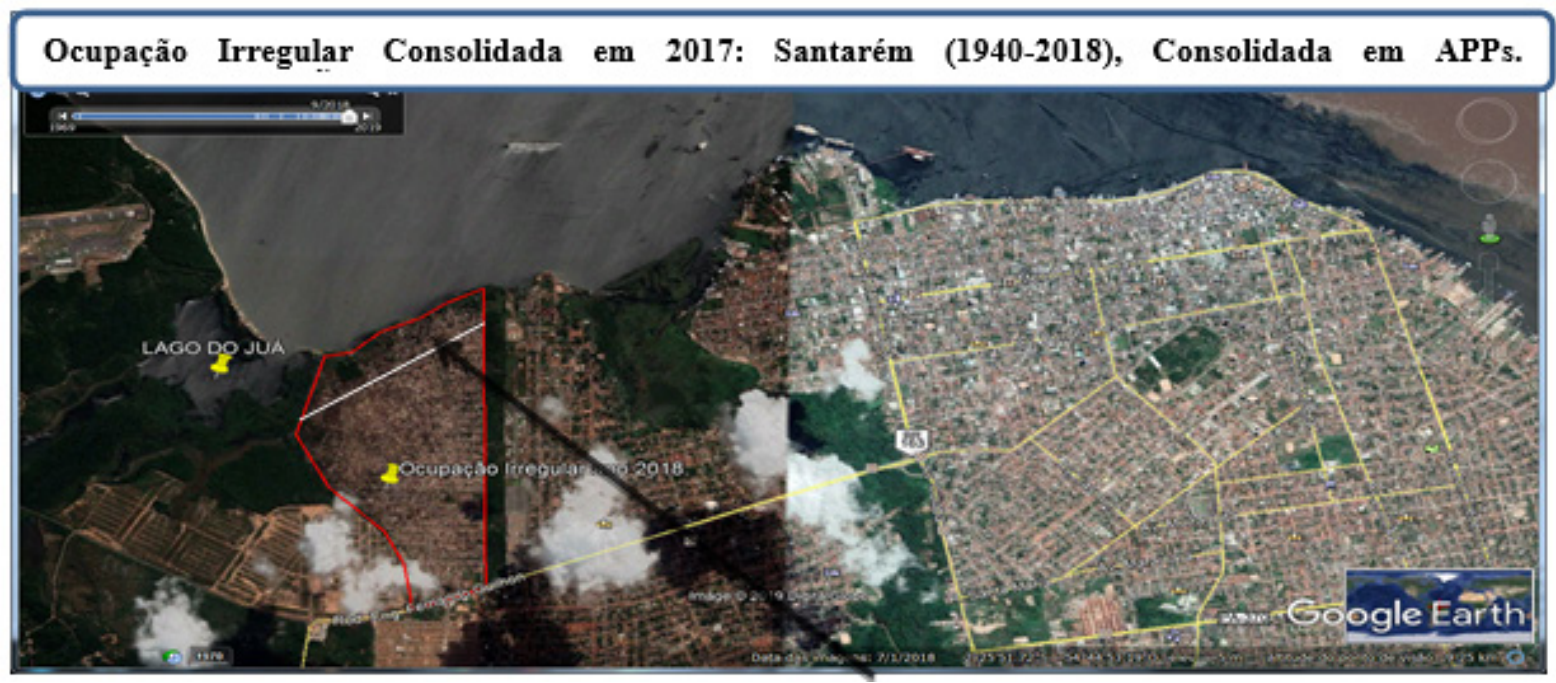

Fonte: Google Earth /2019. APPs consolidadas 
Portanto, o objetivo do presente estudo consiste em analisar as ações já impetradas (a primeira fase, em 2014, de mais de três mil famílias, não faz parte da ação nas APPs), com o intuito de conciliar a permanência da ocupação, e a preservação do meio ambiente, para sua regularização, já que a remoção de mais de 1.400 famílias (dados de 2018), no espaço das APPs do Juá e Tapajós, geraria traumas sociais terríveis.

Ademais, a Associação do Bairro Salvação do Juá, organizada desde o ano de 2010, não está sozinha, juntamente com ela, no polo passivo da ACP, na Ação de Reintegração de Posse, no processo sob o no 0013104-51.2014.8.14.00-51, estão mais 3.00o famílias que fazem parte do bairro Vista Alegre do Juá (Associação fundada em 2010), juntamente com essas 1.400 famílias. (BRASIL, 2014).

Sobre a ação judicial nas APPs do Juá e Tapajós, o Município de Santarém ajuizou ACP, no processo de no. oo03993.38.2017.8.14.0051, em 2017 (BRASIL, 2017b).

Em 2015, a ocupação chegou às APPs em questão. Teve prolação de sentença pelo Juízo $a$ quo, Dr. Claytoney Passos Ferreira, da 6a Vara Cível e Empresarial de Santarém, em o3/o4/2017, concedendo tutela de urgência antecipada em caráter antecedente (art. 303 CPC/2015).

A presente ordem judicial determinava a remoção forçada de todos os moradores da ocupação irregular nas APPs, ao passo que a ação principal fora interposta em o7/o6/2017, sendo proferido julgamento de mérito, em primeira instância, em 19/10/2018, para saída imediata, com fulcro no art. 487, inciso I, do CPC, caso contrário, incorreriam em pena de crime de desobediência.

O fundamento da decisão firmava-se na violação de área na qual não seria lícito ao homem explorá-la, conforme os artigos $3^{\circ}$ e $4^{\circ}$ da Lei no 12.651/2012 (SANTARÉM, 2017).

No entanto, os moradores não foram retirados, por falta de efetivo policial. Pela resposta dada pelo comandante da Polícia Militar do Pará PM/PA, teria que vir reforço de Belém, Pará. (até a presente data, 2019, sem previsão de efetivo policial) (BRASIL, 2017b).

Foi interposto Agravo de Instrumento de no 0408328-46.2018.8.14-0ooo, assinado pelo agravante em 04/o6/2018. No mesmo mês, em Belém-PA, no TJ/PA, na data de 21 de junho de 2018, a Desembargadora Relatora Célia Regina de Lima Pinheiro, diante do risco de dano grave e a probabilidade do direito, nos termos do art. 565 , $\S 1^{\circ}$, do $\mathrm{CPC} / 2015$, determinou o deferimento do pedido de efeito suspensivo deduzido, devendo ser suspensos os efeitos da decisão recorrida.

Isto se deu porque o caso requeria designação de audiência de mediação, pela característica de litígios possessórios coletivos, que visam a retirada de cidadãos instalados no local há mais de ano e dia.

No entanto, na data de 19 de março de 2019 a Desembargadora Célia Regina de Lima Pinheiro, nos termos do art. 932, III do CPC/2015, não conheceu do Agravo, por estar prejudicado, em face da perda superveniente do interesse recursal, pois a liminar foi confirmada, tendo em vista que foi proferido julgamento do mérito, em primeira instância, em 19/10/2018 (BRASIL 2018a).

A Desembargadora se manifestou sobre a incompetência da Justiça Estadual, em o8/11/2018, sob o argumento de que em outra ACP (Proc. no. 1000398.97.2017.4.01.3902) ajuizada pelo Ministério Público Federal (MPF) em desfavor do Estado do Pará, do Município de Santarém e da empresa Sisa Salvação Empreendimentos Imobiliário Ltda-Me, proprietária da área invadida.

Cumpre destacar que o Dr. Juiz Federal Érico Rodrigo Freitas Pinheiro, mencionando as APPs do presente caso, declarou que a competência é da Justiça Federal a análise da ACP do Processo no o003993-38.2017.8.140051. Isto porque, estando às margens de rio federal, configuram-se como bens da União, devido o Rio Tapajós atravessar mais de um estado. A 
apelação, na ação principal, está na iminência de ser julgada pelo TJ/PA na data de o9/o6/2019 (BRASIL 2018a).

Assim, desde 2014, não houve nem a preservação do meio ambiente, com a concessão das liminares, nem tampouco a retirada dos moradores, ou assistência às comunidades locais que fazem parte das ocupações irregulares, enquanto a angústia, temor e o dano ambiental crescem desde então, por não se saber ao certo o que poderá ocorrer no futuro, se será ou não cumprida a reintegração de posse.

A mera apresentação de números, ou a execução das leis, pela força policial, não bastarão para solucionar a problemática ambiental, nem tampouco a remoção forçada dessas pessoas apaziguará os conflitos socioambientais.

Tais atitudes não trarão o respeito do cidadão pelo Estado, pois se a reintegração de posse ocorrer, não será respeitada a especificidade da dinâmica local, não será alcançado o desenvolvimento sustentável, nem a inclusão ou emancipação do cidadão pela sua tradição, seus valores ou suas crenças e sugestões, no meio ambiente ao qual está inserido, como apresentado por Castro (2019), nas seguintes palavras:

A mera apresentação de planos e estudos para essas pessoas não satisfaz o quadro de seleção de informações e consultas anteriores. Mesmo fornecendo abrangentes e compreensíveis informações e dados, isso pode não ser suficiente para atender às necessidades de uma visão teleológica doambiente, o que significa que odesenvolvimento sustentável deve incluir outros fatores que as ciências econômicas e sociais racionais não incluem, como religião e tradição (CASTRO, 2019, p. 363). ${ }^{4}$

Na Bíblia Sagrada, na versão 'NIV 'Study Bible' (1992, p.986), em complemento a essa ideia, é apresentada a forma de solidariedade cristã, do amor a si mesmo, com reflexo para a família humana e, a partir daí, ao meio ambiente, pela garantia necessária à emancipação do indivíduo, para poder permanecer, quando se preocupa com o meio ao qual está inserido.

De maneira solidária e fraterna, os direitos de terceira geração podem ser implementados, como previsto no Evangelho de Mateus, no manual do cristianismo, podendo-se observar uma parte de onde se originou o pensamento constitucional de 1.988, da crença de um povo, como um dos pilares que dão origem à consciência da sustentabilidade, a saber; a máxima cristã, que prescreve: "Honra teu pai e tua mãe: e ama seu próximo como a ti mesmo " (BÍBLIA, 1992, Mt. 19; 19. p. 986). ${ }^{5}$

Portanto, da consciência na ordem imperativa de Cristo, do amor pelo próximo, advém da consciência e medida do amor por si mesmo, logo, conhecer os seus direitos, deveres, limitações e necessidades, prepara o ser individual ao meio ambiente equilibrado, em coletividade .Com a consciência individual de seus direitos e obrigações, bem como das gerações presentes e futuras gerações, extrai-se daí, parte da inteligência do Constituinte, da consciência coletiva de um povo, como se afere na $\mathrm{CR} / 88$, demostrado em seu preâmbulo, como se segue:

\footnotetext{
Nós, representantes do povo brasileiro [...] o bem-estar, o desenvolvimento, a igualdade e a justiça como valores supremos de uma sociedade fraterna, pluralista e sem preconceitos, fundada na harmonia social e comprometida, na ordem interna e internacional, com a solução pacífica das controvérsias, promulgamos, sob a proteção de Deus [...] (BRASIL, 1988).
}

\footnotetext{
4 Tradução livre de: The mere presentation of plans and studies to these people does not satisfy the checkbox of prior information and consultation. Even providing comprehensive and understandable information and data, this might be not enough to meet the ultimate teleological view of the environment, meaning that sustainable development should include other factors that rational economic and social sciences do not include, such as religion and tradition.

5 Tradução livre de: Honor thy father and thy mother: and, Thou shalt love thy neighbor as thyself (BÍBLIA, 1992, Mt. 19; 19. p. 986)
} 
Ali está incluído o meio ambiente, para aqueles que virão após eles, fazendo parte de suas preocupações, quando instituem o Estado Democrático de Direito, entendido como direitos e deveres coletivos, individuais e Inter geracionais, deixando um ambiente participativo, pelo seu legado.

Portanto, é muito importante notar que a expansão da consciência cidadã ocorre quando os valores, crenças e tradições não são anulados pela implementação de políticas públicas ou efetivação dos direitos difusos, para a legitimação da meta norma, do princípio do desenvolvimento sustentável constitucional.

Compreende-se assim que se faz necessário a busca por alternativas que visem compatibilizar o direito social à moradia, a função social da propriedade, a livre iniciativa e a proteção ao meio ambiente, mediante formas eficientes e seguras na ocupação e uso do solo respeitando os valores, crenças e tradições da comunidade local.

Nesse sentido, em 25 de abril de 2019, foi firmado acordo judicial, por meio de TAC, na $2^{\underline{a}}$ Vara Federal da Subseção Judiciária de Santarém/PA, pelo Juiz Federal Érico Rodrigo Freitas Pinheiro, nos autos da Ação Civil Pública no. 1000398-97.2017.4.01.3902, em tramitação na Segunda Vara Federal, entre o Ministério Público Federal, Ministério Público do Pará, a Empresa Sisa Salvação Empreendimentos Imobiliários Ltda, o Município de Santarém, bem como pela Secretária de Meio Ambiente (BRASIL, 2019, p. 2).

Os autos tratam sobre danos e impactos ambientais causados, pela referida empresa, no que tange ao seu empreendimento "Residencial Cidade Jardim", ao Lago do Juá, à sua Área de Preservação Ambiental (APA) e APP. Nele é prescrito compromisso de apresentar Plano de Recuperação de Área Degradada (PRAD), ao órgão ambiental municipal Secretaria Municipal do Meio Ambiente (SEMMA), no prazo máximo de 120 dias, com medidas para mitigação do dano, adequação do empreendimento, como a recomposição da mata ciliar da APP do Lago do Juá, bem como estudo complementar dos Impactos Ambientais (EIA) do empreendimento (BRASIL, 2019, p. 2).

Para a empresa Sisa Buriti, foi possível firmar o TAC, mesmo em detrimento de todos os ocupantes das APPs, pois o acordo firmado entre os órgãos supramencionados e a referida empresa ocorreu sem a participação dos ocupantes e seus procuradores, beneficiando a empresa, sem dar direito à participação dos moradores, como ocorreu no acordo para retirálos compulsoriamente, caso venham a serem cumpridas as reintegrações de posse sobre as no processo de no. oo039933820178140051 (reintegração de posse da APP do Lago do Juá) e no. o0042021220148140051. Segue pontos do acordo:

[...] a empresa doará, ao Município de Santarém, imediatamente, uma área de 200 metros de frente por aproximadamente $\mathbf{2 . 5 0 0}$ metros de fundo (até a margem do Rio Tapajós), que integra a área de ocupação "Bela Vista do Juá", a fim de que nela sejam acomodados os ocupantes que tenham perfil socioeconômico para serem beneficiários de futuro programa de habitação social. [...] a empresa doará ao Estado do Pará, imediatamente, uma área de 18,4138 hectares, às margens do Lago do Juá, a fim de que nela seja edificado futuramente o Centro de Convenções de Santarém. Cláusula Sexta - A empresa doará, ao Município de Santarém, assim que solicitado por este, a área correspondente à Área de Proteção Ambiental do Lago do Juá, no equivalente a 126,3465 há [...] (BRASIL, 2019, p. 2).

Ocorre que a área disponibilizada já está cheia de moradores que fazem parte da ocupação irregular, ademais, o terreno doado pela empresa acolherá somente parte (70o famílias aproximadamente de mais de cinco mil famílias), do Bairro Vista Alegre do Juá, do Bairro Salvação do Juá, respectivamente, e retirará todos os ocupantes restantes bem como todas as 1400 famílias das APPs do Juá e Tapajós. 
Com o objetivo de testar a possibilidade de permanência da ocupação antrópica, em ambas as APPs, no próximo tópico, será apresentada a legislação que trata sobre a temática, para conciliar ambos os interesses, apresentando o TAC, previsto na Lei no 7.347/85, em seu art. $5^{\circ}$, $§ 6^{\circ}$, na LACP, como instrumento para efetivação da Reurb-S, para o caso específico, sob o paradigma da dimensão jurídico-política da sustentabilidade, na obra de Freitas (2016), bem como Gomes e Ferreira (2017), na possibilidade do direito de permanecer.

\section{APLICAÇÃO DA REURB-S PELO TAC NAS APPS DO JUÁ DO TAPAJÓS}

A regularização das ocupações em APPs visa, sobretudo, atender a função social da propriedade, o uso racional do solo, bem como dos recursos naturais disponíveis, enquanto prima-se pela preservação do meio ambiente, e todo o seu equilíbrio, quando se busca a efetivação dos princípios previstos na CR/88, em seus artigos 182, 186, incisos I e II e no artigo 225, $§ 1^{\circ}$, incisos I e III, coluna e baluarte do Direito Ambiental, conjugados com os direitos elencados no art. $5^{\circ}$ XXIII, art. 6o , do direito universal à moradia e das funções sociais da propriedade, trazendo, assim, firme guarida para essas famílias.

Em toda essa dinâmica de leis, direciona-se à finalidade maior, em busca da permanência pela inteligência de uma metanorma, que rege e aponta a direção para todas as outras finalidades, das normas constitucionais e infraconstitucionais, bem como do Direito Internacional, o de conjugar o paradigma multidimensional da sustentabilidade.

Assim, destaca-se no âmbito jurídico-político a obra de Gomes e Ferreira (2017), em interdependência com a comunidade local, como se segue: "uma determinação principiológica vinculante que visa ao aperfeiçoamento da tutela efetiva dos direitos fundamentais para que possam se materializar em bem-estar para as gerações presentes e futuras gerações, num prisma de proteção da vida em suas diferentes formas" (GOMES; FERREIRA, 2017, p. 96).

Mas afinal, o que é sustentabilidade? Para Freitas (2016) o conceito de sustentabilidade tem relação direta com a forma de se alcançar o bem estar. Mas não seria a busca pelo permanecer, expressão sinônima da ideia de sustentabilidade e, que esse direito fosse garantido a todos, na forma inclusiva, por serem os recursos finitos, em um espaço e tempo determinados?

Assim, a busca pelo permanecer sob o paradigma da sustentabilidade não pode ser egoísta, devendo ser equânime e, garantido a todos, o direito de buscar permanecer, como exposto por Freitas (2016), no conceito de sustentabilidade, como se segue:

\footnotetext{
Trata-se do princípio constitucional que determina, com eficácia direta e imediata, a responsabilidade do Estado e da sociedade pela concretização solidária do desenvolvimento material e imaterial, socialmente inclusivo, durável e equânime, ambientalmente limpo, inovador, ético e eficiente, no intuito de assegurar, preferencialmente de modo preventivo e precavido, no presente e no futuro, o direito ao bem-estar (FREITAS, 2016, p. 43).
}

Nesse sentido Gomes e Ferreira (2017), relacionam a sustentabilidade ao equilíbrio ambiental, denotando o direito de todos usufruírem o bem estar ali intrínseco, incluindo o direito a moradia digna em âmbito global, mas também específico, como se segue:

A sustentabilidade denota uma preocupação internacional em promover o pleno desenvolvimento sustentável dos povos e das comunidades de modo a preservar o meio ambiente equilibrado para as gerações presentes e futuras gerações [...] é multidimensional, pois agrupa as dimensões social, ambiental, econômica, ética e jurídico-política, torna-se indispensável complementar cada uma de suas dimensões e suas próprias especificidades (GOMES; FERREIRA, 2017, p. 94). 
Portanto, não se pode falar em sustentabilidade sem o acesso, pelas populações mais pobres, à moradia digna em um ambiente equilibrado, pelo espaço inclusivo de políticas públicas, levando em consideração o direito de cada cidadão de buscar permanecer no ambiente, de maneira digna e, pela situação em que se encontram, mesmo que seja no restante do que sobrou, na falta de oportunidades.

Assim, para abordar a situação das ocupações irregulares, na periferia de Santarém, será necessário apresentar um olhar inclusivo, por leis que versem pela busca do permanecer, de forma razoável e sustentável, em conclusão, dar a eles o direito de permanecer com formas que proporcionem sua regularização, para adequação ambiental nas APPs do Juá e Tapajós.

Com esse intuito, a Lei nº 13.465/2017 que dispõe sobre a regularização fundiária urbana, (Reurb- S e E), remetendo expressamente aos dispositivos $3^{\circ}, 4^{\circ}, 64$ e 65 do Código Florestal (Lei Federal n 12.651/2012), que tratam dos limites das APPs e ocupações irregulares em APPs, em zonas urbanas, conjuga o dever de recuperação de APPs, com o direito de permanecer pela busca na aplicação da sustentabilidade.

Com esse objetivo, a atualização da matéria se faz necessária pelo paradigma da sustentabilidade, em Freitas (2016), já que busca o respeito pela dinâmica social urbana, sob os aspectos diversos em ambas as suas dimensões, para alcançar o direito à moradia digna, tendo como protagonista a comunidade local para construir soluções de forma participativa, como apresentado por Gomes e Ferreira (2017). Neste sentido:

A dimensão social da sustentabilidade enfatiza uma necessária e indispensável preocupação com o ser humano e sua qualidade de bem-estar, pois existe uma íntima relação entre a qualidade de vida do ser humano e a qualidade do meio ambiente, uma vez que são conceitos indissociáveis (GOMES; FERREIRA, 2017, p. 95).

Assim, o ânimo e consciência, para proteção ambiental, estarão na consciência de ter o direito de permanecer efetivado, abrangendo de forma inegociável, quando não vedado pela lei, o direito à moradia digna, pelo próprio direito intrínseco a todo o cidadão, de maneira individual e para os seus filhos.

Pensando a partir desde ponto, no planejamento em longo prazo para seus netos, abrange-se a consciência de solidariedade, fraternidade e meio ambiente, na forma da terceira geração dos direitos humanos e fundamentais, para se conscientizar a preservação do meio ambiente ecologicamente equilibrado para as gerações presentes e futuras gerações, nos termos do artigo 225 e incisos, da CR/88.

Como exposto por Gomes e Ferreira, esse direito engloba tanto os aspectos ambientais, como econômicos, sociais, ambientais e éticos, bem como jurídico-políticos, atendendo, desta forma, todas as dimensões do desenvolvimento sustentável e da sustentabilidade. Assim, visando delimitar os aspectos temporais, físicos e legais do presente caso, far-se-á, no próximo tópico, análise pormenorizada das balizas legais, em questão.

\subsection{Balizas Temporais e Limites Físicos para Aplicação da Reurb-S em Áreas de Preservação Permanente}

A Lei Federal no 12.651/2012, ao introduzir os arts. 64 e 65 no Código Florestal permitiu a regularização de ocupações em APPs urbanas, porém, não deixou claro um limite temporal para estabelecer o objeto de regularização, portanto, far-se-á necessário identificar o limite temporal sobre a temática. 
A MP $n^{\circ}$ 759/2016, revogou o art. 54, § $1^{\circ}$, da Lei Federal $n^{\circ}$ 11.977/2.009 e em seu art. $9^{\circ}$, $§ 2^{\circ}$, estabeleceu que os núcleos urbanos informais, comprovadamente existentes na forma desta Lei, poderiam ser regularizados, até 22 de dezembro de 2016. Esse marco temporal foi incorporado pela Lei Federal n ${ }^{\circ}$ 13.465/2017, para não incorrer em divagações, pela indefinição da Lei n⿳o 12.651/2012, ou por um marco temporal indeterminado no futuro.

Assim, o art. $1^{-}$no $\S 1^{\circ}$, do Decreto no $9 \cdot 310 / 2018$, apresenta os princípios de sustentabilidade econômica, social e ambiental e ordenação territorial, de forma a buscar a ocupação do solo de maneira eficiente, visando combinar o seu uso de forma funcional.

$\mathrm{O} \S 2^{\circ}$, do mesmo artigo, adverte que só poderá ser aplicado o Reurb Social para os núcleos urbanos informais, comprovadamente existentes em 22 de dezembro de 2016, fixando o marco temporal para regularização das ocupações irregulares, consolidadas ou não em APPs.

Embora no art. 8o, § 4º , da Lei Federal n 12.651/2012 haja vedação expressa de supressão de vegetação em APPs, tal dispositivo admite a intervenção, nos casos de interesse social permitidos em lei e de projetos de regularização fundiária de interesse social, em áreas urbanas consolidadas ocupadas por população de baixa renda.

No art. 92, do presente Decreto, admite-se que ele possa ser aplicado até 11 de julho de 2017, para os processos administrativos de regularização fundiária, iniciados pelos entes públicos competentes, até a data de publicação da Lei no 13.465, de 2017 (BRASIL, 2018b).

A Lei Federal n ${ }^{\circ} 6.766 / 1979$ que dispõem sobre o uso e parcelamento do solo urbano limitou as construções em áreas de APPs no limite de 15 metros de cada lado, no decorrer de águas correntes, assim definido no art. 4, III, sem edificações (BRASIL, 2018c, p. 18).

No art. $4^{\circ}$, do atual Código, têm-se as dimensões das APPs, dos rios e lagos, em áreas urbanas, que foram estabelecidos de forma geral, como se segue:

I - as faixas marginais de qualquer curso d'água natural perene e intermitente, excluídos os efêmeros, desde a borda da calha do leito regular, em largura mínima de: [...]. e) $5 \mathbf{5 0}$ (quinhentos) metros, para os cursos d'água que tenham largura superior a 600 (seiscentos) metros; [...] II - as áreas no entorno dos lagos e lagoas naturais, em faixa com largura mínima de: [...] b) 30 (trinta) metros, em zonas urbanas; grifo nosso (BRASIL, 2012)

Dobler e Assunção (2018, p. 167) acrescentam que, com a Lei no 12.651/2012, foram alterados os parâmetros de medição dessas áreas, deixando de mensurar as APPs a partir do nível mais alto das águas, no período da cheia, como era previsto no antigo decreto, mensurando a partir da borda da calha do leito regular, ou seja, um nível médio, reduzindo toda a área que era proporcionada pela vazão e inundação em épocas de cheias.

Avançando na doutrina, de maneira geral, no conceito de APP de forma mais abrangente, não se pode deixar de considerar o intuito de proporcionar, além da proteção ambiental, o bem estar das populações locais.

Tal posicionamento proporciona o acessoàs características inerentes ao desenvolvimento sustentável, percepção basilar para a análise do caso concreto, bem como dos parâmetros que serão fundamentais para fixar as balizas no limite de 500 metros das APPs, trazido pela norma abstrata e geral, às margens dos rios, em zona urbana, devendo serem aplicados os princípios da razoabilidade e proporcionalidade, na definição de sua amplitude.

As APPs em questão estão às margens do Lago do Juá (área de $4.454 \mathrm{mt}^{2}$, em zona urbana, aplicando-se o limite de 30 metros de APP) e do Rio Tapajós (mais de 6oo metros de largura, aplicando-se o limite de 500 metros de APP, pela lei geral). O Rio Tapajós origina-se em Mato Grosso, adentrando o estado do Pará, até desaguar no Rio Amazonas, em frente à cidade de Santarém. 
Diante desta situação, se aplicado o limite de 500 metros, estabelecido pela norma abstrata e geral, às margens do Rio Tapajós, sem considerar as exceções no tempo e espaço, haveria o descolamento de inúmeros moradores do centro da cidade, destruição de portos, cilos, armazéns, cais, construções diversas, avenidas e ruas, com prejuízos milionários para a cidade como um todo, sendo, portanto, impraticável, carecendo de regulamentos próprios e abertura de exceção para o caso específico, como se percebe na imagem abaixo:

Figura 3

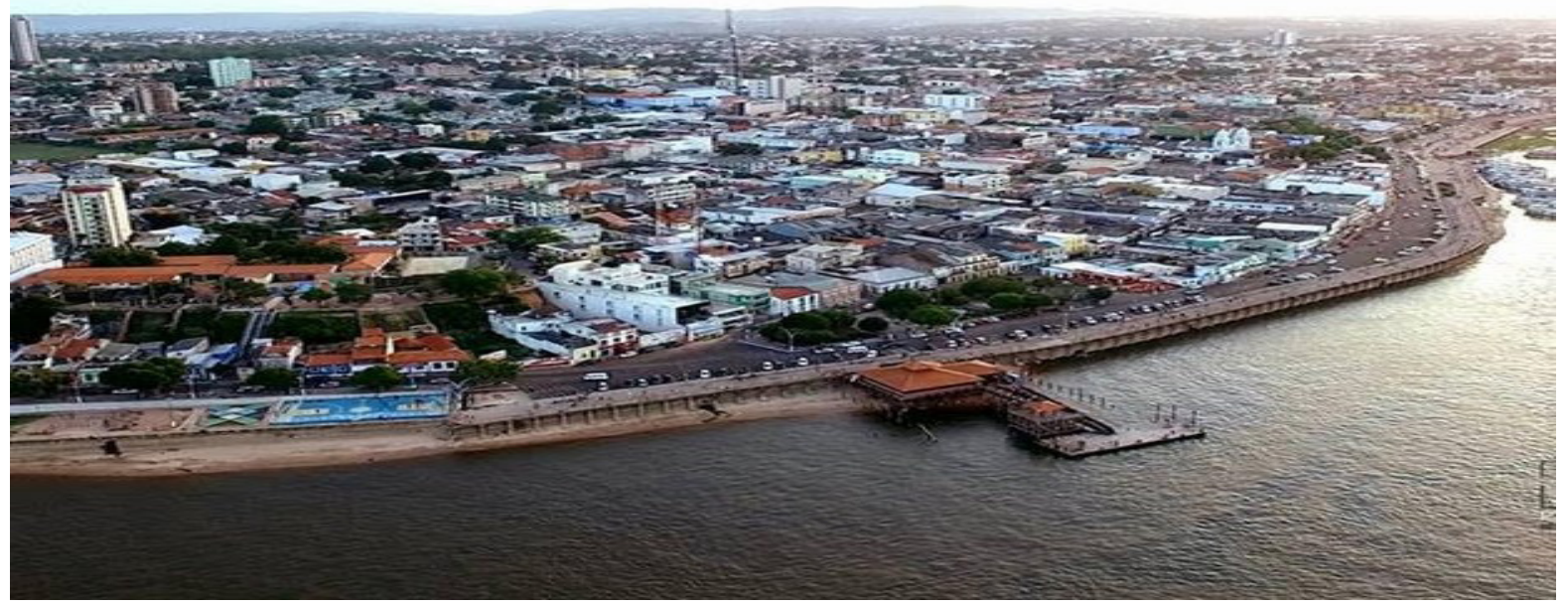

Fonte G1. Karla Lima. 2018. (Foto: Ádrio Denner/ AD Produções)

Como se afere no presente caso, o limite do Decreto no $9 \cdot 310 / 2018$, no art. $4^{\circ}$, $§ 7^{\circ}$, é opção mais razoável e proporcional, pois desconsidera o limite de 500 metros para atender a dinâmica urbana, como segue: "Para fins da regularização ambiental prevista no § 6o, ao longo dos rios ou de qualquer curso d'água, será mantida faixa não edificável com largura mínima de 15 (quinze) metros de cada lado" (BRASIL, 2018b).

Da mesma, forma a Lei oㅜ 12.651/2012, em seu artigo 65, inciso X, § $2^{\circ}$ como se segue: “\$ 2을 Para fins da regularização ambiental prevista no caput, ao longo dos rios ou de qualquer curso d'água, será mantida faixa não edificável com largura mínima de 15 (quinze) metros de cada lado" (BRASIL, 2012).

\subsection{Aspectos Legais para aplicação da Reurb-S em APPs}

A Lei no 12.651/2012, em seu artigo 64, trouxe a possibilidade de regularização das ocupações urbanas em APPs, por meio da aprovação do projeto de regularização fundiária, exigindo, no $\S 1^{\circ}$, do mesmo artigo, estudo técnico que demonstrasse a melhoria das condições ambientais, em relação à situação anterior e, no $§ 2^{-}$, os elementos que deveriam constar no presente estudo.

Também na mesma Lei, o art. $3^{\circ}$, inciso IX, alínea d, também trouxe a previsão do instituto da regularização fundiária urbana (Reurb S-E), em APPs, considerando como interesse social os assentamentos humanos ocupados predominantemente por população de baixa renda em áreas urbanas (BRASIL, 2012).

A partir da Lei no 12.651/2012 (atual Código Florestal), não mais se exigiu a comprovação de inexistência de alternativa locacional, para manter a caracterização do regime de proteção 
legal dessas áreas. No mesmo Código, em seu artigo $3^{\circ}$, definiu-se o conceito de APP, levando em consideração o bem estar das populações humanas, pela proteção socioambiental, como se segue:

\footnotetext{
[...] área protegida, coberta ou não por vegetação nativa, com a função ambiental de preservar os recursos hídricos, a paisagem, a estabilidade geológica e a biodiversidade, facilitar o fluxo gênico de fauna e flora, proteger o solo e assegurar o bem-estar das populações humanas [...] (BRASIL, 2012).
}

Em complemento à compreensão da inteligência do artigo 64, estão os objetivos da Reurb-S, nomeados no art. $2^{\circ}$, do Decreto no 9.310/2018, dentre eles se destaca o objetivo de: "III - ampliar o acesso à terra urbanizada pela população de baixa renda, de modo a priorizar a permanência dos ocupantes nos próprios núcleos urbanos informais". (BRASIL, 2018b). Logo, a compreensão é no sentido de permitir e dar condições da comunidade local permanecer nas APPs, desde que atendam os requisitos legais para melhoria nas condições ambientais.

Ademais, pelas características especificas das APPs em zonas urbanas, em questão, demanda a aplicação do princípio da razoabilidade e proporcionalidade, em consonância com o princípio da dignidade humana e do desenvolvimento sustentável, para essas aglomerações urbanas em APPs.

Tal entendimento visa estabelecer o limite inferior aos 500 metros estabelecido pela regra geral às APPs rurais. Isto porque Santarém foi construída às margens do Rio Tapajós, sem o acompanhamento de políticas públicas que atendessem a expansão urbana pelo Município, Estado e União, se tornando impraticável a remoção forçada de todos das APPs do centro da cidade, mas seria razoável retirar aproximadamente 1.400 famílias das ocupações irregulares consolidadas nas APPs do Juá e Tapajós, desde 2016 ?

Nesse sentido, dentre os objetivos do Reurb-S, nomeados no art. $2^{\circ}$, do Decreto no 9.310/2018 estão: "III - ampliar o acesso à terra urbanizada pela população de baixa renda, de modo a priorizar a permanência dos ocupantes nos próprios núcleos urbanos informais e $\mathrm{V}$ estimular a resolução extrajudicial de conflitos, em reforço à consensualidade e à cooperação entre Estado e sociedade"(BRASIL, 2018b).

A Lei Municipal no 18.051/o6, em seu art. 119 e 120, §1ํㅡ, estabelece o Plano Diretor de Santarém e prevê a regularização de assentamentos espontâneos bem como a possibilidade de participação popular na tomada de decisões e no Parágrafo Único do art. 120, que a urbanização deverá em todas as suas etapas ser desenvolvida com a participação direta dos moradores e de suas diferentes formas de organização quando houver (SANTARÉM, 2006, p. 39).

Portanto, a falta de efetivação e eficiência no modelo adotado das tutelas de urgência, que ficaram aquém da proteção ambiental e da participação da comunidade local, exige formas que acompanhem o nascimento dos sonhos de cada cidadão, quando se luta pelo direito à moradia digna, mesmo que seja às margens do que sobrou pela falta de oportunidade.

No entanto, na realidade presente, teme-se pela destruição do seu esforço, do que já está feito, sobressaindo-se o dever de administrar os direitos e deveres dos cidadãos, pela direção educativa e participativa dos entes governamentais, como proposta de resolução, pelo TAC, sobre preservação do meio ambiente, com apoio técnico, estrutura e planejamento.

Sob esse parâmetro, com vistas a atender o que é necessário para a efetividade do direito prometido no texto constitucional, consequentemente, acolher os seus deveres em contrapartida e se adequar às exigências de proteção desse direito, não somente das gerações futuras, mas também na luta pelo direito do cidadão presente e de sua família, atendendo a solidariedade humana intergeracional. 
Sob essa perspectiva, no próximo tópico, será abordado o TAC, como proposta para a efetivação do Reurb Social nas ocupações irregulares dentro das APPs.

\section{O TERMO DE AJUSTAMENTO DE CONDUTA COMO INSTRUMENTO PARA EFETIVAÇÃO DA REURB-S, NAS AREAS DE PRESERVAÇÃO PERMANENTE DO JUÁ E TAPAJÓS}

O presente trabalho propõe a construção da resolução da problemática ambiental pelos entes governamentais e a sociedade, por meio do TAC, nos termos do parágrafo $6^{\circ}$ do artigo $5^{\circ}$ da LACP, por intermédio do Ministério Público. O TAC consiste em dar a oportunidade para o responsável pelo dano ambiental assumir o compromisso de evitar ou remover o ilícito, e/ou de reparar o dano, como nos expõem Rodrigues e Klippel (2009):

O Termo de Ajustamento de Conduta é um dos métodos pelos quais se exerce a composição do litígio no Estado Contemporâneo, que deve prestar atenção aos novos direitos, que não se tutelam satisfatoriamente por meio do tradicional método do ressarcimento pecuniário e necessitam de técnicas alternativas de composição, expandindo, pois, o acesso à ordem jurídica justa (RODRIGUES; KLIPPEL, 2009, p. 218).

Assim, no caso em questão, o TAC se torna instrumento para a efetivação do Reurb-S na medida em que obriga formalmente a comunidade local a se ajustar às disposições normativas incidentes naquilo que as leis supramencionadas permitem, não abrindo mão da reparação do direito difuso indisponível, mas, pelo contrário, tornando possível a sua proteção e/ou reparação de forma efetiva.

A atuação coparticipava da comunidade torna o negócio jurídico válido, de maneira efetiva, pois a atuação acontece de imediato, com exigência certa líquida e exigível, imediatamente após a formalização do acordo, com tempo determinado, tendo eficácia de título executivo extrajudicial, nos termos do artigo $5^{\circ}$ da LACP, $§ 6^{\circ}$, demostrado a seguir: "Os órgãos públicos legitimados poderão tomar dos interessados compromisso de ajustamento de sua conduta às exigências legais, mediante cominações, que terá eficácia de título executivo extrajudicial" (BRASIL, 1985).

Portanto, apresenta-se projeto ambiental e formas de melhoria das condições ambientais na área a ser regularizada, sendo explicitado no Decreto no 9.310/18, os seus requisitos, como:

[...] Condições de sustentabilidade urbano-ambiental, considerados o uso adequado dos recursos hídricos, a não ocupação das áreas de risco e a proteção das unidades de conservação, quando for o caso; VI - comprovação da melhoria da habitabilidade dos moradores propiciada pela regularização proposta; e VII - demonstração de garantia de acesso livre e gratuito pela população às praias e aos corpos d'água, quando couber (BRASIL, 2018b).

Como requisitos específicos, pode-se requerer a substituição imediata de todas as fossas negras por fossas cépticas, barreiras de contenção da enxurrada, recuperação das áreas degradas no entorno do Lago do Juá e do Tapajós, no limite de 70 metros, como já foi apresentada proposta pela Presidente da Associação do Bairro Salvação do Juá.

Destaca-se, também, educação ambiental de forma efetiva com a obrigatoriedade de cumprir, por cada morador, horas aula ou palestras, estipuladas pelo órgão competente, coleta de lixo de imediato com destinação mais apropriada, definida pelos órgãos competentes dentre outras sugeridas em coparticipação. 
Não consta na regularização vigente o requisito de ter que comprovar a falta de alternativa locacional, nem a consolidação da ocupação, mas exige-se a comprovação do assentamento ter ocorrido antes de 22 de dezembro de 2016 , previsto no art.9, §2º 13.465/2017 (BRASIL, 2017a).

Isto, levando em consideração as dimensões dos aglomerados urbanos, o entorno dos rios, córregos e lagos, com largura de no mínimo 30 metros, em espaços urbanos, tratadas as características das APPs, do Juá e Tapajós e da análise das ações em curso, tornando-se essencial a possível aplicação das leis ora mencionadas e suas especificidades, na análise do caso concreto, para possível viabilidade de sua regularização pelo TAC.

Porém ressalta-se, como exortado por, Gomes e Rossi (2016, p. 26o), que há de se ter cautela na aplicação do TAC, pois se trata de instrumento embasado por critérios e instrumentos técnico-científicos de garantia mínima, sendo necessário, para que ocorra sua homologação judicial, melhorias efetivas nos aspectos socioambientais que, por sua vez, sirvam de forro e manto que firmem e cubram a coisa julgada, pois, em regra, não mais será possível discutir as obrigações ali tratadas depois de homologadas judicialmente.

Nesse sentido também orienta Ferreira e Gomes (2019, p. 73), ressaltando o princípio da indisponibilidade, limitando o Ministério Público (MP) a utilizar-se do TAC como instrumento para a efetivação do direito à moradia, sem dispor do bem ambiental, não podendo renunciar ou diminuir a proteção dos direitos difusos, apenas adequar o cumprimento para sua recuperação, por prazos determinados e formas especificadas.

Portanto, seguindo a orientação legal e doutrinária, adequando o cumprimento às condições legais e havendo melhorias nas condições socioambientais, haverá a possibilidade da permanência da ocupação irregular nas APPs do Juá e Tapajós, garantindo a proteção suficiente do meio ambiente e provendo o direito à moradia digna, efetuando os direitos sociais inerentes ao Estado Democrático de Direito, em um ambiente comunitário-participativo.

\section{CONSIDERAÇÕES FINAIS}

Assim, como foi apresentada na proposta inicial, a hipótese para o presente artigo sobre a possibilidade regularização das ocupações antrópicas nas APPs do Juá e Tapajós, analisou-se mais profundamente as Leis no $12.651 / 12$, no $13.465 / 17$ e o Decreto no 9.310/218, dos marcos temporal, físico e legal, bem como a análise do caso concreto, no Processo no o00399338.2017.8.140051, com Tutela Provisória em Caráter Antecedente, e a Ação de Reintegração de Posse, no processo sob o no 0013104-51.2014.8.14.00-51.

Para a consecução dos resultados, fez-se abordagem teórico-jurídica assentada em método hipotético-dedutivo com técnicas de pesquisa bibliográfica, com a análise da Lei no 13.465, de 11 de julho de 2017, que dispõe sobre Reurb-E-S, tendo como referencial teórico, a obra de Gomes e Ferreira (2017), sobre as dimensões Jurídico-Políticas da Sustentabilidade, bem como análise do Decreto no 9.310, de 15 de março de 2018, tendo em vista os direitos elencados no art. 6o e 225 da CR/1988, requerendo a aplicação do TAC, no caso em comento.

Para tanto, no primeiro capítulo apresentou-se breve histórico na formação do conceito de APP, a evolução de sua proteção e os diplomas legais e atuais sobre a temática.

No segundo tópico apresentou-se o estudo de caso das APPs no Lago do Juá e Rio Tapajós, corroborados de estatísticas, com dados oficiais sobre a realidade local, o panorama de sua judicialização e mapas para melhor visualização.

No terceiro tópico empenhou-se em analisar a amplitude do direito à moradia e do desenvolvimento sustentável e os seus pormenores, sobre a Reurb-S, abrangendo, no quarto 
tópico, o Termo de Ajustamento de Conduta, como instrumento eficaz para sua aplicação, com intuito de alcançar a satisfação das dimensões do Desenvolvimento Sustentável, em ambas as suas facetas, desenvolvendo propostas para preencher os requisitos impostos, seja de medidas compensatórias, reparatórias ou para proteção, com fins ao nível de impacto ambiental desejável, em busca da conciliação ente o Direito à Moradia e o Desenvolvimento Sustentável.

Constatou-se que as legislações supramencionadas trouxeram novos requisitos e hipóteses de supressão de vegetação em área de preservação permanente, de forma excepcional, como previsto no art. 8 e 64, $§ 1^{\circ}$, do atual código, a saber; nos casos de utilidade pública, interesse social (Reurb-S) e baixo impacto ambiental.

Também se constatou que a ocupação ocorrida de forma irregular nas APPs do Juá e Tapajós, se consolidou em 2016, conforme imagens de satélites e características da estrutura interna de ambas as APPs, em área urbana.

Constatou-se que no local há sistema viário (ruas e avenidas), organizado em quadras e lotes, predominantemente edificados (casas, comercio, indústrias), equipamentos de infraestrutura urbana, implantados, como: distribuição de energia elétrica, limpeza urbana

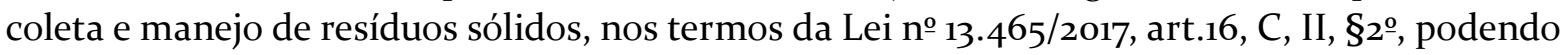
ser considerada como núcleo informal urbano consolidado, segundo o artigo $3^{\circ}$, do Decreto $\mathrm{n}^{\circ}$ 9.310/2.018.

A atual situação da ocupação se encontra em estado de difícil reversão, considerados o tempo da ocupação, a natureza das edificações, a localização das vias de circulação e a presença de equipamentos públicos, entre outras circunstâncias a serem avaliadas pelo Município ou pelo Distrito Federal.

Pôde-se concluir que, as leis supracitadas, exigem como requisito para a regularização, aprovação de projeto ambiental e formas de melhoria das condições ambientais na área a ser regularizada.

Se for cumpridos requisitos que garantam melhorias dessas condições socioambientais apresentando formas específicas de mitigação do dano e recuperação do ambiente, de forma que seja possível a preservação do meio ambiente é possível sua regularização e permanência nas APPs.

Isso decorre de não constar restrições na legislação vigente, nem entraves que não possam ser solucionados com a participação da comunidade, se tornando essencial a aplicação das leis ora mencionadas, suas especificidades, na análise do caso concreto, para possível viabilidade de sua regularização pelo TAC.

Concluiu-se que se deve considerar o ensino da morada mãe ao homo/sapiens/cordato, sobre o direito à educação ambeintal, tendo como substrato a amálgama da informação, dos diferentes pontos de vista, na percepção da realidade, provados pela razão.

Essa consciência do ser e do dever ser, do poder e do poder ser, ambos iluminados pela razão, que insculpe nas mentes incautas, a responsabilidade de se afastar da ignorância, de construir oportunidades e valores, do permanecer ou não, com um bom planejamento elaborado de antemão.

O direito à moradia se consubstancia pela oportunidade de permanência e continuidade. Tendo como escopo o direito à moradia como suporte à empregabilidade, oriunda do fruto da habilitação e capacitação do cidadão, com fins à pluri aptidão, inclusão e emancipação, pelo diálogo e alternativa. Não pela voz dos que clamam às portas, querendo arrancar as raízes humanas da terra, que criam o vínculo de mãe e filho na motivação para o conhecimento e proteção. 
Não da derrubada do esforço do trabalho, nas margens do que sobrou, fora dos direitos da pátria amada, separados pela força do braço forte, longe do ensino, do diálogo e inclusão, expressões da mãe gentil, na solução de conflitos urbanos.

Com esse intuito o presente artigo teve como proposta apresentar alternativas à brutalidade nas reintegrações de posse e remoções forçadas que geram tantos traumas sociais e celeumas humanas.

Nesse sentido apresentou-se o TAC como medida que respondesse efetivamente à morosidade de um ordenamento jurídico estático e das tutelas de urgência, alheias ao clamor local, que não atendem a problemática socioambiental.

Sob essa proposta buscou-se apontar alternativas que aproximassem os entes governamentais à comunidade, em todos os seus anseios, para elaboração de políticas públicas e soluções pacíficas, que viessem garantir o direito à moradia em um ambiente ecologicamente equilibrado, denotando a necessidade da elaboração de leis atuais com a participação popular, em consonância com as exigências constitucionais.

A Lei do Reurb Social é alternativa que consubstancia razoavelmente a relação entre o homo/sapiens/cordato e a morada natureza, pelo TAC, na efetivação da Reurb Social.

'Se faz necessária a efetivação do princípio da sustentabilidade e proporcionalidade para aqueles que estão fora do diálogo, dos direitos da pátria amada, separados pelo braço forte do Estado na execução das tutelas de urgência, que são alheias ao clamor local.

Tem-se com o presente artigo, um velado convite para a percepção da mãe natureza, em querer permanecer e deixar que seus filhos permaneçam, com afagos recíprocos, na realidade tão amórfica desses ocupantes, diferente da busca pela felicidade, corolário do cidadão máximo, garantida pela constituição, empoderada por vestimentas legais da justiça socioambiental, para permanecer em sua terra/casa, mas neste caso, morada instável, perturbada e aguerrida.

\section{REFERÊNCIAS}

BÍBLIA SAGRADA. N.T. ed. São Paulo: A Nova Versão Internacional da Bíblia de Estudo. (The NIV Study Bible), 1992.

BRASIL. Tribunal de Justiça do Estado do Pará. Agravo de Instrumento de Processo no 0408328-46.2018.8.14-0ooo, o4/o6/2018. Poder Judiciário do Tribunal de Justiça do Estado do Pará. 2018a. Belém- 2º Grau. Pje-Processo Judicial Eletrônico $1^{\mathfrak{a}}$ Turma de Direito Público Órgão julgador: Desembargadora Célia Regina de Lima Pinheiro.

BRASIL. Tribunal de Justiça do Estado do Pará. Apelação de Ação de Reintegração Posse. Processo no oo13104-51.2014.8.14.0051. Poder Judiciário do Tribunal de Justiça do Estado do Pará. 2014. Belém- 2o Grau. PJe -Processo Judicial Eletrônico. Desembargadora Célia Regina de Lima Pinheiro. 27/o8/2018..

BRASIL. Tribunal de Justiça do Pará. Decisão Interlocutória. 2017. no o32163481. Processo no o003993-38.2017.8.14.0051. Liminar; 03/04/2017b. Poder Judiciário do Tribunal de Justiça do Estado do Pará. Santarém. Secretaria da 6a vara cível e empresarial de Santarém. 
BRASIL. Poder Judiciário. Acordo Judicial Num. 49442946 - Pág. 2 Ação Civil Pública no. 1000398-97.2017.4.01.3902. Subseção Judiciária de Santarém-PA 2ª Vara Federal Cível e Criminal da SSJ de Santarém-PA 2.019. Acordo Judicial, 2019. Disponível em http://www. mpf.mp.br/pa/saladeimprensa/documentos/2019/termo_acordo_judicial_1000398 -97-2017-4013902_49442946_lago_jua_santarem-pa_abril_2019.pdf. > Acesso em: 14 abr. 2019.

BRASIL. Constituição da República Federativa do Brasil de 1988. Diário Oficial da União, Brasília, o5 out. 1998. Disponível em: http://www.planalto.gov.br/ccivil_o3/constituicao/ constituicao.htm. Acesso em: 15 mai. 2018.

BRASIL. Decreto no 9.310, de 15 de março de 2018b. Institui as normas gerais e os procedimentos aplicáveis à Regularização Fundiária Urbana e estabelece os procedimentos para a avaliação e a alienação dos imóveis da União. Diário Oficial da União, Brasília, 16 mar. 2018a. Disponível em: http://www.planalto.gov.br/ccivil_03/_ato2015-2018/2018/decreto/D9310.htm. Acesso em: 16 jun. 2019.

BRASIL. Regularização Fundiária Urbana em Áreas de Preservação Permanente. Ministério Público Federal. Série Manuais de Atuação no 6. Brasília. 2018c.

Brasil. Lei no 4.771, de 15 de setembro de 1965. Instituía O Antigo Código Florestal. Revogada pela Lei no 12.651, de 2012. On-Line. Brasília, 15 de setembro de 1965; 144º da Independência e 77º da República. Diário Oficial da União, Brasília, 16 set. 1965. Disponível em: http://www. planalto.gov.br/ccivil_03/leis/L4771.htm. Acesso em: 14 maio 2018.

BRASIL. Lei no 7.347, de 24 de julho de 1985. Disciplina a Ação Civil Pública de Responsabilidade por Danos Causados ao Meio Ambiente, ao Consumidor, a Bens e Direitos de Valor Artístico, Estético, Histórico, Turístico e Paisagístico (Vetado) e dá Outras Providências. Diário Oficial da União, Brasília, 25 jul. 1985. Disponível em: http://www.planalto.gov.br/ccivil_03/leis/ l7347orig.htm. Acesso em: 14 maio 2019.

BRASIL. Lei no 12.651, de 25 de maio de 2012. Dispõe sobre a proteção da vegetação nativa; altera as Leis nos 6.938, de 31 de agosto de 1981, 9.393, de 19 de dezembro de 1996, e 11.428, de 22 de dezembro de 2006; revoga as Leis nos 4.771, de 15 de setembro de 1965, e 7.754, de 14 de abril de 1989, e a Medida Provisória no 2.166-67, de 24 de agosto de 2001; e dá outras providências. Diário Oficial da União, Brasília, 28 maio 2012. Disponível em: http://www.planalto.gov.br/ ccivil_03/_ato2011-2014/2012/lei/l12651.htm. Acesso em: 14 maio 2018. 
BRASIL. Lei no 13.465 , de 11 de julho de 2017a. Dispõe sobre a regularização fundiária rural e urbana, sobre a liquidação de créditos concedidos aos assentados da reforma agrária e sobre a regularização fundiária no âmbito da Amazônia Legal; institui mecanismos para aprimorar a eficiência dos procedimentos de alienação de imóveis da União; altera as Leis n os 8.629, de 25 de fevereiro de 1993, 13.001, de 20 de junho de 2014 , 11.952, de 25 de junho de 2009, 13.340, de 28 de setembro de 2016, 8.666, de 21 de junho de 1993, 6.015, de 31 de dezembro de 1973, 12.512, de 14 de outubro de 2011 , 10.406, de 10 de janeiro de 2002 (Código Civil), 13.105, de 16 de março de 2015 (Código de Processo Civil), 11.977, de 7 de julho de 2009, 9.514, de 20 de novembro de $1997,11.124$, de 16 de junho de 2005, 6.766, de 19 de dezembro de 1979, 10.257, de 10 de julho de 2001, 12.651, de 25 de maio de 2012, 13.240, de 30 de dezembro de 2015, 9.636, de 15 de maio de $1998,8.036$, de 11 de maio de 1990, 13.139, de 26 de junho de 2015, 11.483, de 31 de maio de 2007, e a 12.712, de 30 de agosto de 2012, a Medida Provisória no 2.220, de 4 de setembro de 2001, e os Decretos-Leis n o 2.398, de 21 de dezembro de 1987, 1.876, de 15 de julho de 1981, 9.760, de 5 de setembro de 1946, e 3.365, de 21 de junho de 1941; revoga dispositivos da Lei Complementar no 76, de 6 de julho de 1993, e da Lei no 13.347, de 10 de outubro de 2016; e dá outras providências. Diário Oficial da União, Brasília, o8 set. 2017. Disponível em: http://www.planalto.gov.br/ ccivil_03/_ato2015-2018/2017/lei/l13465.htm. Acesso em: 14 maio 2018.

BRASIL. Regularização Fundiária Urbana em Áreas de Preservação Permanente. Ministério Público Federal, Brasília, no 6, 2018c. Disponível em: http://www.mpf.mp.br/atuacaotematica/ccr4/dados-da-atuacao/publicacoes/roteiros-da-4accr/o5_18_Manual_de_Atuao_ APP_ONLINE.pdf. Acesso em: o8 jun. 2019.CASTRO, Douglas de. the resurgence of old forms in the exploitation of natural resources: the colonial ontology of the prior consultation principle. Veredas do Direito: Direito Ambiental e Desenvolvimento Sustentável, Belo Horizonte, v. 16, no 34, p. 343-365, maio 2019. Disponível em: doi:http://dx.doi.org/10.18623/rvd. v16i34.1387. Acesso em: 10 jun. 2019.

COLLECTIF, “ Outils juridiques pour la protection des espaces naturels “, Crozet S., ministère de l'Ecologie et du développement durable, GIP Atelier technique des espaces naturels, délégation à l'Aménagement du territoire et à l'action régionale, ministère des Transports, de l'équipement, du tourisme et de la mer, Office national des forêts, Conservatoire de l'espace littoral et des rivages lacustres, ministère de l'Agriculture et de la pêche, éd. Medd-Aten, 2010, Cahiers techniques ${ }^{\circ} 78$. ISBN : 2-912801-70-2.

CONSELHO NACIONAL DO MINISTÉRIO PÚBLICO. Resolução no 179, de 26 de Julho de 2017. Regulamenta o § 60 do art. $5^{\circ}$ da Lei no 7.347/1985, disciplinando, no âmbito do Ministério Público, a tomada do compromisso de ajustamento de conduta. Diário Eletrônico do CNMP, Brasília, 26 jul. 2017. Disponível em: http://www.cnmp.mp.br/portal/images/Resolucoes/ Resolu\%C3\%A7\%C3\%A30-179.pdf Acesso em: 10 jun. 2019.

CRIVELLARI, Júlio César Teixeira. Novo código florestal: suas implicações no contexto da sustentabilidade socioeconômica ambiental. Belo Horizonte: D’ Plácido, 2016.

DOBLER, Gustavo; ASSUNÇÃO, Aldo Fernando. O Regime Jurídico das Áreas de Preservação Permanente no Código Florestal (Lei 12.651/2012), á luz do princípio da proibição do retrocesso: estudo a partir da Lei 4.771/65, e da Constituição Federal. 2018, p. 159-184. Revista de Direito Ambiental. Vol. 89 ano 23 São Paulo: Ed. RT, Jan-Mar. 2018 
FERREIRA, Leandro José. GOMES, Magno Federici. F368p. A Participação Popular na Proteção do Meio Ambiente Pela Via do Processo Justo. - Belo Horizonte, 2019. 234 f. Dissertação (Mestrado) - Escola Superior Dom Helder Câmara. Orientador: Prof. Dr. Magno Federici Gomes Referências: f. 219- 2341. CDU 349.6:502.7(043.3). Disponível em: http://domhelder.edu.br/posgraduacao/editor/assets/arquivos_dissertacoesdefendidas/ a53cbf6bcbd4d2b7a58505e749e26ac5.pdf >. Acesso em: 14 jun. 2019.

FREITAS, Juarez. Sustentabilidade: direito ao futuro. 3. ed. Belo Horizonte: Fórum, 2016.

GOMES, Magno Federici; FERREIRA, Leandro José. A Dimensão Jurídico-Política da Sustentabilidade e o Direito Fundamental à Razoável Duração do Procedimento. Revista do Direito, Santa Cruz do Sul, v. 2, no 52, p. 93-111, maio/set. 2017. Disponível em: https://online. unisc.br/seer/index.php/direito/index. Acesso em: o9 jun. 2019.

GOMES, Magno Federici; ROSSI, Camila. O Termo de Ajustamento de Conduta Como Instrumento Processual de Proteção do Meio Ambiente. Revista do Mestrado em Direito da Universidade Católica de Brasília: Escola de Direito. RVMD, Brasília, V. 10, № 2, p. 247263, Jul-Dez, 2016.

GOOGLE. Earth. Fotos satélite; situação da área (2018). APPs consolidadas. Disponível em: HTTPS://www.google.com.br/intl/pt-BR/earth/. Acesso em: o1 jun. 2019.

IBGE. Instituto Brasileiro de Geografia e Estatística. 2019. Disponível em: https://ibge.gov.br/. Acesso em: o1 jun. 2019.

PARÁ. Ministério Público do Pará. Promotoria de Justiça do Meio Ambiente, Patrimônio Cultural e Habitação e Urbanismo de Santarém. Ata da Reunião, 21 de Janeiro de 2018. Disponível em: https://www2.mppa.mp.br/resultado-de-busca/?query=ata+reuni\% $\mathrm{C}_{3} \% \mathrm{~A}_{3}$. Acesso em: 10 maio 2019 .

RODRIGUES, Marcelo Abelha; KLIPPEL, Rodrigo. A Homologação Judicial do TAC e a Formação da Coisa Julgada Coletiva em Matéria Ambiental. In: FIGUEIREDO, Guilherme José Purvin de; RODRIGUES, Marcelo Abelha (Coord.). O novo processo civil coletivo. Rio de Janeiro: Lumen Juris, 2009. p. 215-233.

SANTARÉM. Lei n 18.051 , de 29 de dezembro de 2006. Institui o plano diretor participativo do município de Santarém. Gabinete da Prefeita Municipal de Santarém, Santarém, 29 dez. 2006. Disponível em: https://sogi8.sogi.com.br/Arquivo/Modulo113.MRID1o9/Registro65436/ lei\%2on\%C2\%Bo\%2018.051,\%20de\%2029-12-2006.pdf. Acesso em: 20 abr. 2019.

SANTOS, Boaventura de Sousa. Para uma Revolução Democrática de Justiça. São Paulo: Cortez, 2011.

SOUZA, Luiza de Marilac; VIANA, Raquel de Mattos (Coord.). Déficit Habitacional no Brasil (2015). Belo Horizonte: Fundação João Pinheiro, 2018. Cap. 3. Pg. 1-78. Disponível em: http:// fjp.mg.gov.br/index.php/docman/direi-2018/871-6-serie-estatistica-e-informacoes-deficithabitacional-no-brasil-2015291118/file. Acesso em: 14 maio 2019. 